The lesson for nervous policymakers, she says, could be: "Hang on, things are changing over time."

But it took an epic political struggle to pass the most ambitious social legislation in decades and now, a month from congressional elections, Republicans are making a strong play for control of the House of Representatives and appear likely to make gains in the Senate. Tea party activists scored key victories in primary races, edging the Republican's roster of candidates even farther to the right.

To be sure, unraveling the massive Patient Protection and Affordable Care Act is a tall order. For all of their calls to "repeal and replace" it, Republicans know that if they somehow passed legislation to strike the law or parts of it, Obama would exercise a veto. But Congress controls federal spending and that's where foes can create roadblocks by holding back money.
"Without the president, we can't repeal it," concedes Senator Mitch McConnell of Kentucky, the Republican Senate leader. "But we can go after portions of it aggressively."

The fight goes on in court, too. Twenty states have challenged the insurance mandate in what supporters of the law at first dismissed as a desperate gambit to skirt the legislative process (CMAJ 2010;DOI:10.1503 /cmaj.109-3223). But the first court to take it up, in Virginia, refused the government's request to dismiss the suit.

Meantime Washington is busily writing cheques in a series of stopgap benefits until the full weight of the reforms kicks in.

Nearly four million elderly or disabled people on US Medicare are now getting one-time payment of US $\$ 250$ apiece to help pay drug costs not covered under the plan. The government is spending US $\$ 5$ billion to help employ- ers offer affordable coverage for early retirees under 65 - too young for Medicare. The subsidy vastly trims health care costs for that vulnerable segment of the population until the meatiest reforms are in place, mostly 2014. Then, new competitive insurance markets will exist, no one of any age will risk losing coverage or being denied insurance by being sick, hefty federal aid for affordable policies will flood to citizens and businesses, and older people will no longer pay crushingly higher premiums than the young.

People who have yet to see the pluses and minuses of the new ways are almost certain to by then. That's if the law makes it to 2014. Two other key dates come first: the elections of 2010 and 2012, both shaping Congress and the second deciding the presidency. Cal Woodward, Washington DC

DOI:10.1503/cmaj.109-3666

\title{
United States to compel physicians to make "meaningful use" of electronic health records
}

Previously published at www.cmaj.ca

$\mathrm{T}$ he contrast is startling. The United States government recently adopted regulations that will compel — and generously pay - American physicians to make "meaningful use" of electronic health records (EHRs).

But in Canada, the financial incentives aren't as lucrative and no doctor is under obligation to actually use EHRs, even if they use government monies to purchase the technologies. As a consequence, EHR uptake remains low despite programs such as the province of Ontario's \$386-million EHR incentive program.

Under economic recovery legislation passed in 2009, the US government plans to spend as much as US\$27 billion in EHR incentive payments to physicians over 10 years commencing in May, 2011. Doctors will be eligible to receive as much as US\$63000, and hospitals may also receive millions of dollars for using federally-certified EHRs.

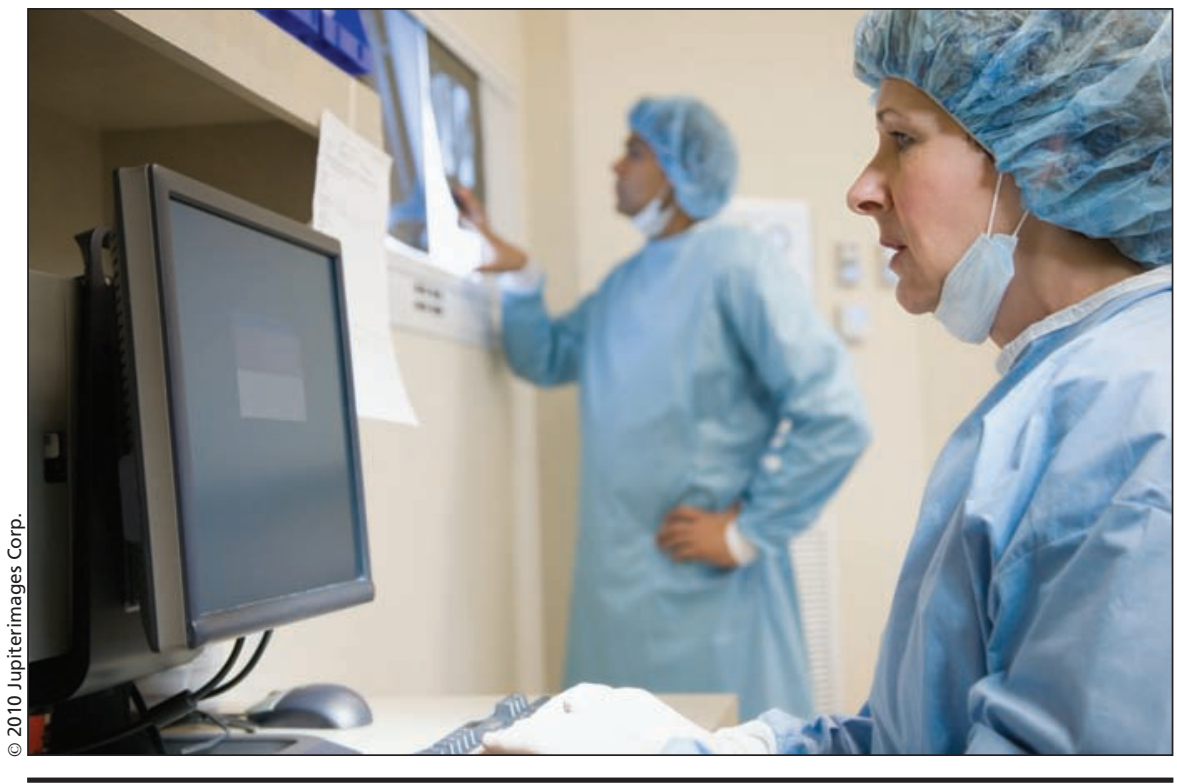

American doctors will receive as much as US\$63 000 to purchase and use federallycertified electronic health record technologies.

The US regulations, published July 28 , are designed to ensure that the government's investment leads to "meaningful use" and rapid adoption of EHRs (http://edocket.access.gpo.gov/2010/pdf /2010-17207.pdf).

To help forge an electronic health revolution, the US regulations set out a 
tight timetable for government efforts to certify a complex array of electronic health information systems and software that will stitch together the national health infostructure.

Once the certification process is completed later this year, the government hopes to move quickly to entice health care providers to apply for federal funding to purchase EHR systems.

But unlike an Ontario program that by April 2012, will pay up to 9000 physicians as much as $\$ 29800$ to buy EHR systems, US physicians will be required to clearly prove that they are making appropriate use of their government-provided technologies.

While the American Medical Association (AMA) approves of the initiative, it has warned that "the tight timeline for adoption and the high overall number of measures physicians are required to meet" are burdensome. "The final rule requires physicians to meet 20 measures in the first year which is still too high, especially for smaller practices that are new to the technology," the AMA complained.

According to the AMA, the US government "expects EHR systems that support meaningful use to become available this fall, giving physicians just a few months to purchase, implement and assess the usability of EHR technology before the January 1, 2011, start date of the incentive program. This is no small feat, considering it can take a year or more to purchase and implement an EHR system."

In a panel session at a gathering of EHR experts in Vancouver, British Columbia, in June, Dr. David Blumenthal, the US national coordinator for health information technology, described the meaningful use regulations as a "powerful organizing concept" aimed at transforming US healthcare by driving down costs while improving healthcare (http://e-health conference.com/).

His enthusiasm was warmly received by Canada Health Infoway President Richard Alvarez: "We're going to be a lot more directive," Alvarez pledged after expressing admiration for a more interventionist approach toward EHR uptake. "We're learning from them."

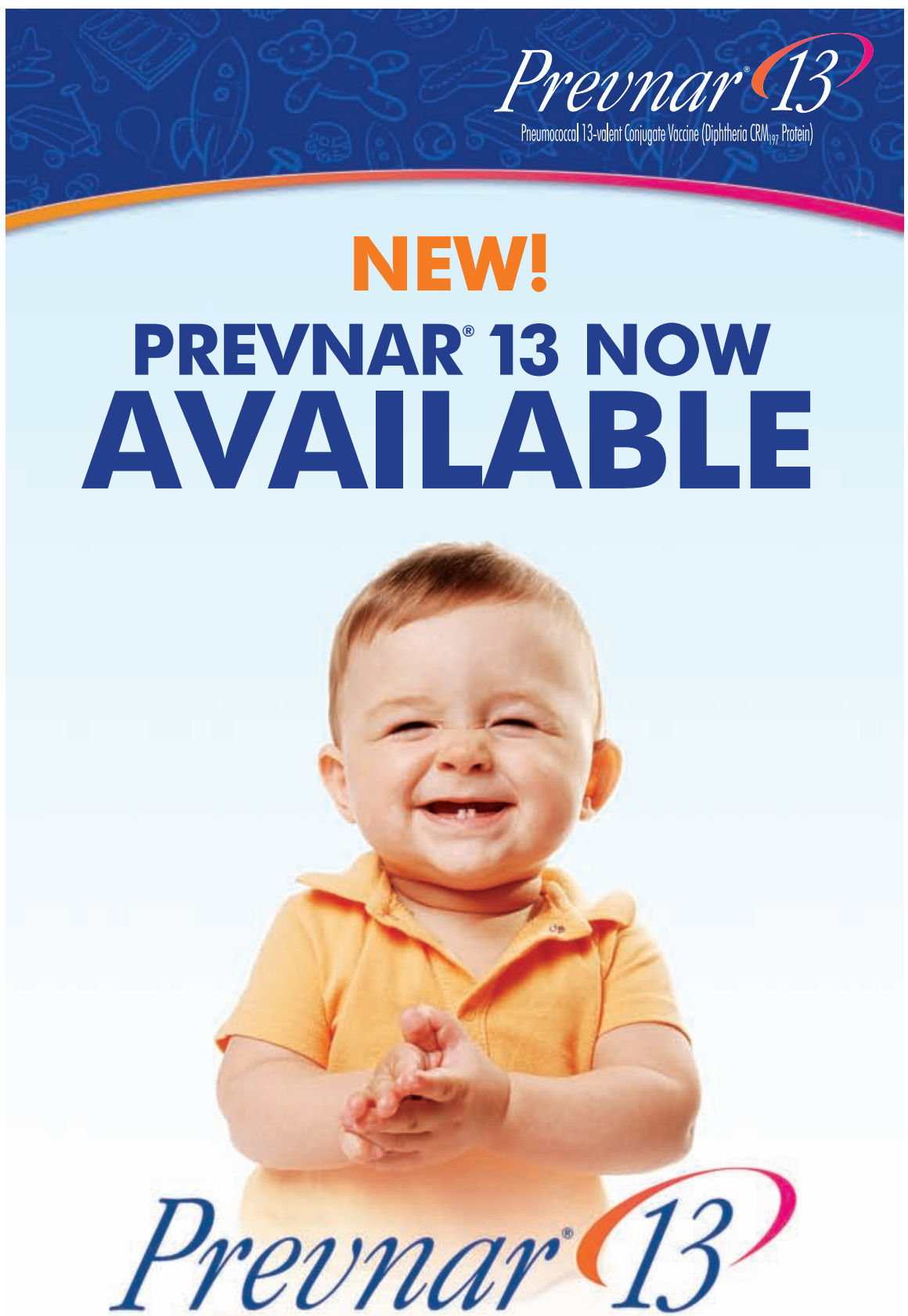

Prevnar 13 is indicated for the active immunization against Streptococcus pneumoniae serotypes $1,3,4,5,6 \mathrm{~A}, 6 \mathrm{~B}, 7 \mathrm{~F}, 9 \mathrm{~V}, 14,18 \mathrm{C}, 19 \mathrm{~A}, 19 \mathrm{~F}$ and $23 \mathrm{~F}$ causing invasive pneumococcal disease, including:

- Sepsis, meningitis, bacteraemic pneumonia, pleural empyema and bacteraemia

- Indicated for use in infants and children from 6 weeks through 5 years of age

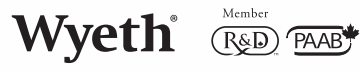

() 2010 Wyeth Canada
Montréal, Canada H4R $1 \mathrm{J6}$ 
Alvarez said that while EHRs are taking root in some parts of the country, notably Alberta, progress has been marred by high turnover in provincial health bureaucracies and opposition among health care providers in other parts of the country. "We ran up against a whole lot of clinician groups," he said.

Alvarez also noted that political leadership is an issue: "If this is not on your premier's agenda, you don't have a chance."

Canadian analysts say the time may have come to adopt the US approach.

David Ludwick, general manager of the Sherwood Park — Strathcona County Primary Care Network in Alberta, says Canadian provinces should require that government-subsidized EHRs are properly used.

In a recent study of EHR certification efforts in seven countries and five provinces, Ludwick found that Saskatchewan and Manitoba have begun to link fee-for-service payments to EHR utlilization, a pattern which he describes as "a type of meaningful use requirement" (Healthcare Quarterly 2009; 12[3]:111-23).

Canadian politicians and EHR officials need to be far more aggressive about forcing providers to join the ehealth revolution, he says. Canadian Health Infoway and provincial agencies such as eHealth Ontario should stop linking payments to installation of EHRs and instead borrow from the US approach by insisting on meaningful use.

Regulations will be needed to do that, he warns. "What do we gain if we pay for the installation of these technologies and then we don't use them? Look at all the money we are pouring in and all the wastage. How hard will it really be to get laws passed?"

Toronto, Ontario-based physician and ehealth consultant Karim Keshavjee notes that an internal 2008, study for the Ontario Ministry of Health and Long-Term Care and the Ontario Medical Association, found that overall, "not a lot of meaningful use" of EHRs has been made.

Keshavjee adds that only $40 \%$ of doctors were found to use EHRs for managing prevention and screening activities. "And although $90 \%$ of physicians use it for 'e-prescribing', there are no electronic connections for those prescriptions to flow, so they print them off and give them to their patients on paper."

Keshavjee strongly endorses the US approach, even if implemented strictly at the provincial level. "It would be more efficient if they were defined federally, but since health care is regulated provincially, it makes more sense to have them regulated at the provincial level," he says. — Paul Christopher Webster, Toronto, Ont.

DOI:10.1503/cmaj.109-3361

Eleventh in a series on electronic health records

Part I: Canada's electronic health records initiative stalled by federal funding freeze (www.cmaj.ca/cgi/doi/10.1503/cmaj.109-3183)

Part II: Ontario's plan for electronic health records is at risk, official says (www.cmaj.ca/cgi/doi/10.1503/cmaj.109-3193)

Part III: Electronic health records a "strong priority" for US government (www.cmaj.ca/cgi/doi/10.1503/cmaj.109-3218)

Part IV: The pocketbook impact of electronic health records: PRO (www.cmaj.ca/cgi/doi/10.1503/cmaj.109-3225)

Part V: The pocketbook impact of electronic health records: CON (www.cmaj.ca/cgi/doi/10.1503/cmaj.109-3226)

Part VI: National standards for electronic health records remain remote (www.cmaj.ca/cgi/doi/10.1503/cmaj.109-3239)

Part VII: National electronic health records initiative remains muddled, auditors say (www.cmaj.ca/cgi/doi/10.1503/cmaj.109-3242)

Part VIII: New electronic health record blueprint to call for increased patient participation (www.cmaj.ca/cgi/doi/10.1503/cmaj.109-3265)

Part IX: Albertans to gain electronic access to personal health files (www.cmaj.ca/cgi/doi/10.1503/cmaj.109-3270)

Part X: Canadian hospitals make uneven strides in utilization of electronic health records (www.cmaj.ca/cgi/doi/10.1503/cmaj.109-3288)

\section{More news at www.cmaj.ca}

\begin{abstract}
Cadaver shows stir controversy: Coating skinless human cadavers in liquid plastic and charging humans still living in their skin an admission fee to take a look has become a lucrative business but critics are concerned that some exhibits do not obtain consent from either the deceased people on display or their families. — Roger Collier, CMAJ
\end{abstract}

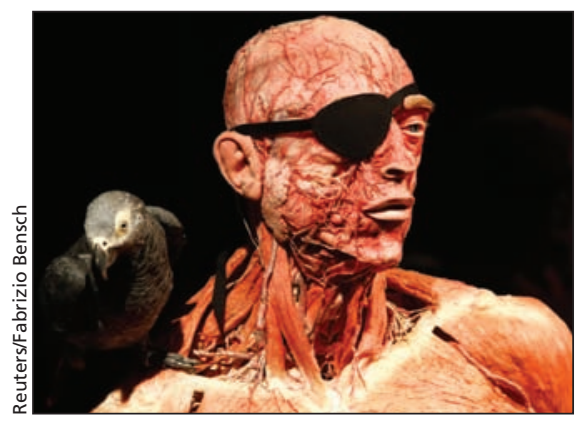

Mediterranean diets: financial crisis prompts trimming of health care's waistline: They've been pejoratively dubbed the "PIGS" of southern Europe: Portugal, Italy, Greece and Spain. Their financial indebtedness has necessitated bailouts from the European Union and other international institutions, and as they scramble to sort out their wrecked 